\title{
PENGEMBANGAN PEMBELAJARAN FIKIH KELAS X MADRASAH ALIYAH DALAM MODEL DICK \& CAREY
}

\author{
H. M. Natsir \\ (Fakultas Tarbiyah dan Keguruan IAIN Mataram)
}

\begin{abstract}
Abstrak:
Keterbatasan perangkat dan kemampuan mengajar guru akan berdampak pada kualitas keluaran kompetensi siswa. Mata pelajaran Fikih di kelas X Madrasah Aliyah memiliki karakteristik yang lebih kompleks daripada mata pelajaran yang sama di jenjang sebelumnya. Fikih di Madrasah Aliyah mulai mengenalkan konsep-konsep yang lebih rumit dalam lingkup hubungan antar manusia, seperti perekonomian dalam Islam atau pelepasan dan perubahan kepemilikan harta. Hal ini menuntut penulis untuk melakukan pengembangan pembelajaran yang lebih efektif dan efisien dengan menggunakan model Dick and Carey. Model ini memiliki karakteristik sistematis yang melibatkan pengembangan, implementasi, evaluasi, dan pemeliharaan hasil pembelajaran. Hasil pengembangan bahan ajar, buku panduan guru, buku panduan siswa, dan desain media pembelajaran memperoleh hasil evaluasi yang yang sangat baik.
\end{abstract}

Kata Kunci: Pengembangan; Pembelajaran; Fikih; Madrasah Aliyah; Dick \& Carey.

\begin{abstract}
:
Limitation of teaching aids availability and teacher competence will impact the quality of students' competence. The Fiqh lesson in the first grade of Islamic High School has a more complex dimension compared to that of in previous grades. The Fiqh in the high school level covered a more complex concept regarding the relationship between individuals in society, e.g. Islamic economy or the release and the change in property ownership. This motivate the author to develop the lesson more efficiently and effectively ny using Dick and Carey Model. This model is characterized by systematic steps in the lesson involving the development, implementation, evaluation, and preservation of learning outputs. The result of the development shows good grade in terms of learning materials, teacher's book, student's book, and learning aids.
\end{abstract}

Keywords: Development; Learning; Fiqh; Islamic High School; Dick \& Carey. 


\section{A. Pendahuluan}

Kondisi guru dalam konteks pembelajaran di Nusa Tenggara Barat khususnya Lombok Barat dan Kota Mataram belum memperlihatkan diri sebagai guru profesional sesuai tuntutan Undang-Undang Nomor 14 Tahun 2005 tentang Guru dan Dosen sebagaimana termuat pada Bab II Pasal 2 ayat 1 dan 2 yang menyatakan bahwa guru mempunyai kedudukan sebagai tenaga profesional yang dibuktikan dengan sertifikat pendidik. ${ }^{1}$ atau yang diperoleh melalui proses sertifikasi pendidikan. ${ }^{2}$

Dan hal tersebut bertentangan dengan pernyataan Allah swt. dalam surat al-Isra' ayat 36:

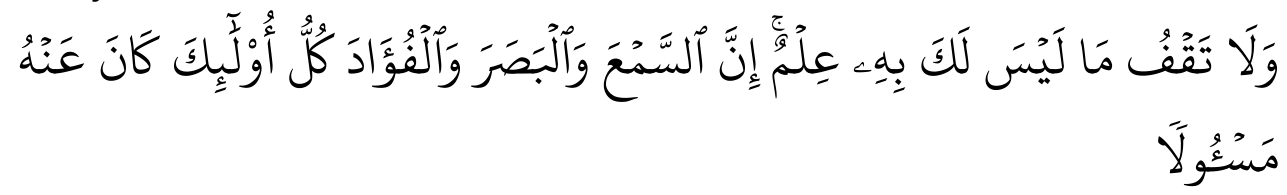

"Dan janganlah kamu mengikuti apa yang kamu tidak mempunyai pengetahuan tentangnya. Sesungguhnya pendengaran, penglihatan dan hati, semuanya itu akan diminta pertanggungan jawabnya. (Q.S. Al-Isra' : 36 ). ${ }^{3}$

Al-Maraghi dalam menafsirkan ayat di atas menyatakan bahwa "jangan seseorang mengatakan "saya telah mendengar", padahal dia belum pernah mendengar, atau "saya telah melihat" padahal dia tidak pernah melihat, atau "saya telah mengetahui" padahal dia belum tahu", sebab pernyataan-pernyatan tersebut memiliki konsekwensi pertanggung jawaban di hadapan Allah swt. di akhirat berkenaan dengan pemanfaatan telinga, mata dan hati. ${ }^{4}$

Tuntutan undang-undang dan pernyataan Allah swt. di atas dapat dijadikan inspirasi bagi para ilmuan pendidikan dalam upaya merumuskan teoriteori pendidikan untuk dikaji oleh guru dalam upaya memperkuat profesinya sebagai guru profesional yang dituntut (1) mempunyai komitmen pada siswa dan PBM, (2) menguasai secara mendalam mata pelajaran yang diajarkannya, (3) bertanggung jawab memantau hasil belajar melalui berbagai cara evaluasi, (4)

1 Undang-Undang Republik Indonesia Nomor 14 Tahun 2005, Tentang Guru dan Dosen : Dilengkapi Undang-Undang Sistem Pendidikan Nasional Peraturan Pemerintah Standar Nasional Pendidikan Peraturan Menteri Buku Teks Pelajaran (Jakarta : Karya Gemilang, 2008), 4.

${ }^{2}$ Abdorrakhman Ginting, Esensi Praktis Belajar \& Pembelajaran : Disiapkan untuk Pendidikan Profesi dan Sertifikasi Guru-Dosen. Edisi Revisi (Bandung : Humaniora, 2008), 11.

3 Kementerian Agama RI, Al-Qur'an dan Terjemahannya Disertai Asbabun Nuzul (Jakarta : Yayasan Penyelenggara/Penafsir Al-Qur'an Revisi Terjemah oleh Lajnah Pentashihan Mushaf Al-Qur'an Kementerian Agama Republik Indonesia, 2013), 285.

4 Ahmad Musthafa Al-Maraghi, Terjamah Tafsir Al-Maraghi, Juz 15 (Semarang : Toha Putra, 1993), 84. 
mampu berpikir sistematis, dan (5) merasa dirinya merupakan bagian dari masyarakat belajar dalam lingkungan profesinya. ${ }^{5}$

Dalam kenyataannya tuntutan tersebut di atas masih sangat kontradektif ketika guru melaksanakan pembelajaran dimana kegiatan ini merupakan suatu kombinasi yang tersusun meliputi unsur-unsur manusiawi, material, fasilitas, perlengkapan, dan prosedur yang saling mempengaruhi untuk mencapai tujuan pembelajaran ${ }^{6}$. Dan juga kontradektif pula ketika mengaitkan tugas guru dalam menjalankan empat peran utamanya dalam kegiatan pendidikan dan pembelajaran yaitu merencanakan kegiatan belajar dan pembelajaran, menyiapkan kegiatan belajar dan pembelajaran, menyelenggarakan kegiatan belajar dan pembelajaran, dan mengevaluasi hasil belajar dan pembelajaran. ${ }^{7}$

Guru dalam menjalan tugas profesinya, sangat memerlukan ketersediaan bahan ajar yang didukung dengan media pembelajaran sesuai dengan materi ajar. Mengingat keberadaan bahan ajar termasuk media dalam kegiatan pembelajaran akan dapat mempertinggi proses belajar siswa dalam pengajaran yang pada gilirannya diharapkan dapat mempertinggi hasil belajar yang dicapainya ${ }^{8}$. Karenanya tuntutan guru untuk menyiapkan rancangan bahan ajar yang bermedia menjadi suatu keharusan sebagai wujud profesionlitasnya.

Ketersediaan bahan ajar sebagai pedoman bagi guru dalam pelaksanaan pembelajaran tidak sebatas memuat materi materi pembelajaran yang dirancang dalam beberapa bab dan sub bab namun juga memuat alat ukur yang dapat dimanfaat kan baik oleh guru maupun siswa untuk menilai pembelajaran baik

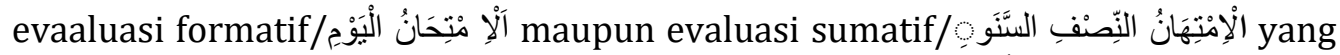
mengarah pada pemenilai pengetahuan/kognitif (آلنَّاحِيَةُ الْفِكْرِيَّة), sikap/afektif

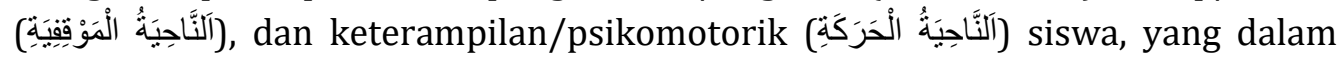
Islam identik dengan iman, ilmu, dan amal.

Di mana ketiga bangun epistimologi ini juga secara substantib dalam pandangan Islam memiliki hubungan yang membuatnya merupakan suatu rangkaian dari nilai-nilai dasar keislaman yang berposisi strategis dalam menuntun seseorang untuk menjadi muslim yang baik atau menjadi muslim yang mukmin dan bertaqwa kepada Tuhan (vertikal) sekaligus terhadap sesama manusia dan alam (horizontal).

5 Buchari Alma, dkk, Guru Profesional : Menguasai Metode dan Terampil Mengajar (Bandung: Alfabeta, 2009), 133.

6 Zainal Aqib, Profesionalisme Guru dalam Pembelajaran (Surabaya : Insan Cendekia, 2002), 41.

7 Ginting, Esensi Praktis Belajar \& Pembelajaran, 14-15.

${ }^{8}$ Nana Sudjana dan Ahmad Rivai, Media Pengajaran (Bandung : Sinar Baru Algensindo, 2009), 2. 


\section{B. Pembahasan}

\section{Pengembangan Pembelajaran}

\section{a. Kedudukan Pengembangan dalam Teknologi Pendidikan}

Munculnya media dalam pembelajaran memiliki sebutan yang beragam selain teknologi pembelajaran juga teknologi pendidikan, meskipun dalam kajian teori istilah teknologi pembelajaran merupakan bagian dari istilah teknologi pendidikan. Naumn hal ini dilakukan dalam upaya memberikan kemudahan penyebutan bagi semua pihak dan terlebih guru yang akrab dengan kegiatan pembelajarannya, sebab istilah teknologi pembelajaran itu sendiri merupakan penyempitan dari istilah teknoligi pendidikan, ini didasarkan atas pertimbangan bahwa istilah teknologi pembelajaran lebih dapat diterima oleh kalangan luas dan lebih fokus pada objek formal yang menjadi garapannya. ${ }^{9}$ Dewasa ini kedua istilah tersebut baik teknologi pendidikan maupun teknologi pembelajaran ternyata digunakan secara bersamaan dan dalam makna yang sama.

Teknolgi pembelajaran dinyatakan sebagai sebuah teori dan praktik dalam mendesain, pengembangan, pemnfaatan, pengelolaan, dan evaluasi proses, serta sumber belajar,10 sehingga dapat dipastikan di dalamnya memupat komponen (1) teori dan praktik, (2) desain, pengembangan, pengelolaan dan penilaian, (3) proses dan sumber belajar, serta (4) terapan belajar dan pembelajaran. Meskipun pada kajian-kajian literatur lainnya seperti di dalam Teknologi Pembelajaran Tahun 1994, ditemukan lima bidang cakupan dalam teknolgi pembelajaran yang terdiri dari perancangan, pengembangan, pemanfaatan, pengelolaan dan penilaian, yang kelima bidang cakupan tersebut merupakan bidang kajian dalam teknologi pembelajaran. Dalam aplikasinya kelima bidang cakupan teknolgi pembelajaran itu memiliki hubungan yang sangat kuat dan saling melengkapi antara kawasan yang satu dengan lainnya.

Bahkan Seels \& Richey ${ }^{11}$ menggambarkan keterkaitan yang sangat erat kelima komponen dalam teknologi pembelajaran tersebut sebagaimana tertuang dalam bagan berikut :

\footnotetext{
${ }^{9}$ Ysufhadi Miarso, Menyemai Benih Teknologi Pendidikan (Jakarta : Prenada Media, 2004), 15. 10 B.B. Seels \& Richey R.C., Instructional Technology: The Definition and Domain of the Field (Washington DC: AECT, 1994), 5.

11 Seels, Instructional Technology, 7.
} 


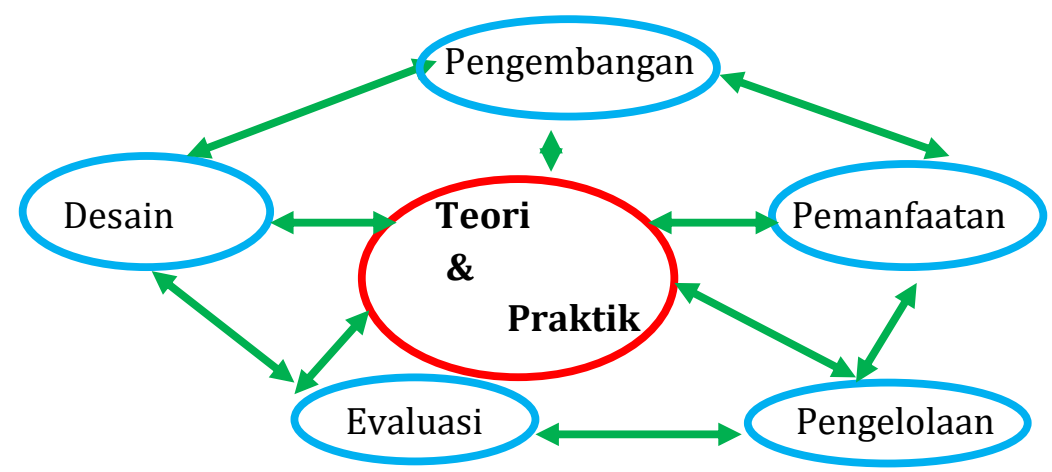

Bagan : Alur Hubungan dalam Definisi Teknologi Pembelajaran

Komponen pengembangan terdiri dari teknologi cetak, teknologi audiovisual, teknologi berbasis komputer, dan teknologi terpadu, Komponen pemanfaatan terdiri dari pemanfaatan media, difusi inovasi, implementasi dan institusionalisasi, kebijakan dan regulasi, Komponen pengelolaan terdiri dari manajemen proyek, manajemen sumber, manajemen sistem penyampaian, dan manajemen informasi, Komponen evaluasi terdiri dari analisis masalah, pengukuran acuan patokan, evaluasi formatif, dan evaluasi sumatif, Komponen perancangan terdiri dari desaian sistem pembelajaran, desain pesan, strategi pembelajaran, dan karantristik pebelajar.

Hubungan kelima kawasan dalam pengertian teknologi pembelajaran di atas mendapat dukungan dari Miarso, dengan pernyataannya bahwa pada awalnya teknologi pendidikan/pembelajaran itu sendiri merupakan suatu bidang kajian khusus (spesialisasi) ilmu pendidikan dengan objek formal "belajar" pada manusia atau yang tergabung dalam organisasi. Bidang kajian ini pada awalnya digarap dengan mensintesiskan berbagai disiplin ilmu ke dalam usaha terpadu. ${ }^{12}$

Dalam contoh terapan keterkaitan kelima kawasan teknologi di atas dapat digambarkan yaitu bila seorang peneliti ingin menekankan pada salah satu kawasan umpamanya pengembangan, maka harus mendasari penelitian pengembangannya itu dengan kawasan desain, seperti teori desain sistem pembelajaran, setrategi pembelajaran, karakatristik pebelajar/siswa, dan desain pesan.

Pengembangan dalam kaitannya dengan pembelajaran sebagai bagian dari kawasan teknologi yang oleh Gustafson, dalam Association for

12 Ysufhadi Miarso, Menyemai Benih Teknologi Pendidikan, 18.

Jurnal Pendidikan Agama Islam (Journal of Islamic Education Studies)

Volume 5 Nomor 1 (2017)

ISSN(p) 2089-1946\& ISSN(e) 2527-4511

Hal. 48 - 67 
Educational Communi cations and Technology (AECT) memberikan pengertian yaitu Instructional development A systematic approach to the design, production, evaluation, and unilization of complete systems of instruction, including all appropriate components and a management patter for uthing them; instructional development is large than instructional product development, which is concerned whith only isolated products, and is large than instructional design, which is only one phase of instructional development.13 (Pengembangan pembelajaran adalah suatu pendekatan sistem yang meliputi rancangan, produk (hasil), evaluasi dan bahan pembelajar an yang dilengkapi dengan petunjuk, sejumlah bagian yang relevan dan pengelolaan terhadap sejumlah bagian tersebut. Dalam pengertian yang lebih luas pengembangan pembelajaran merupakan pengembangan hasil pembelajaran, dengan menekankan pada hasil, dan rancangan pembelajaran yang lebih luas yang di dalamnya memuat tahapan-tahapan pengembangan pembelajaran).

Istilah pengembangan yang digunakan dalam kegiatan pembelajaran sering dikonotasikan dengan penelitian pengembangan, ini dimaksudkan menurut Wayan Ardana adalah untuk menjembatani antara penelitian dan praktik pendidikan. Hal ini timbul karena dorongan teori dan desain harus tanggap terhadap tuntutan penilaian fomatif dan praktik pemanfaatan serta kebutuhan pengelolaan. Sehingga kawasan pengembangan mencakup banyak variasi teknologi yang digunakan dalam pembelajaran. Begitu pula, kawasan pengembangan tidak terdiri hanya seperangkat keras (hardware) pembelajaran, melainkan juga mencakup perangkat lunak (sofware), bahan-bahan visual, dan audio serta program atau paket yang merupakan paduan beberapa bagian. ${ }^{14}$

Pengembangan sebagai bagian dari kawasan teknologi juga di dalamnya memuat (1) teknologi cetak, yang merupakan cara memproduksi atau menyampaikan bahan-bahan seperti buku-buku dan bahan-bahan visual yang statis, terutama melalui percetakan mekanik atau fotografis, (2) teknologi Audio Visual, yang merupakan cara memproduksi dan menyampai kan bahan dengan menggunakan peralatan mekanis dan elektronik untuk menyajikan pesan-pesan audio dan visual, (3) teknologi Berbasis Komputer, yang merupakan cara memproduksi dan

13 K.L. Gustafson, Survey of Instructional Development Models with an Annotated ERIC Bibliography (New York: Syracuse University, 1981), 2.

14 I Wayan Ardhana, "Konsep Penelitian Pengembangan dalam Bidang Pendidikan dan Pembelajaran." Makalah disajikan dalam Lokakarya Nasional Angkatan II Metodologi Penelitian Bidang Pendidikan dan Pembelajaran (Malang,: 22 - 24 Maret 2002). 
menyampaikan bahan dengan menggunakan perangkat yang bersumber pada mikroprosesor, dan (4) teknik terpadu, yang merupakan cara untuk memproduk dan menyampaikan bahan dengan memadukan beberapa jenis media yang dikendalikan melalui komputer. ${ }^{15}$

Dengan demikian pengembangan dalam konteks pembelajaran dan konteks penelitian pengembangan, pada dasarnya memberikan pemahaman tentang bahwa kawasan pengembangan memiliki sejumlah perangkat yaitu pesan yang akan didorong oleh isi, setrategi pembelajaran yang didorong oleh teori, dan manifestasi fisik dari teknologi perangkat keras (hardware), perangkat lunak (sofware) dan bahan pembelajaran. Dan ternyata pengembangan dalam teknologi pembelajaran merupakan bagian yang integral dari kawasan teknologi pembelajaran, yang dalam terapannya akan selalu bersinergi dengan kawasan teknologi pembelajaran lainnya.

\section{b. Kedudukan Bahan Ajar dalam Peningkatan Kualitas Pembelajaran}

Bahan ajar yang dijadikan acuan dalam kegiatan pembelajaran baik oleh guru maupun siswa memiliki kedudukan yang sangat penting dalam upaya peningkatan kualitas pembelajaran, hal ini mengingat bahan ajar merupakan suatu proses yang sistematis dalam mengidentifikasi, mengembangkan, mengevaluasi bahan dan strategi pembelajaran yang diarahkan untuk mencapai tujuan pembelajaran. ${ }^{16}$ Juga sebagai bahanbahan yang digunakan dosen dan mahasiswa dalam proses perkuliahan. ${ }^{17}$ Bahan ajar dapat juga dikatakan sebagai sarana belajar yang berfungsi membantu membelajarkan siswa secara sistematis, terarah sesuai tujuan yang telah ditetapkan. Bahan ajar sangat membantu siswa dalam memahami konsep, prosedur, dan teori. Sedangkan bagi guru dengan penyediaan dan pemanfaatan bahan ajar dapat memberikan bimbingan kepada siswa untuk lebih aktif dalam mengikuti pembelajaran dan lebih cermat dalam mengkaji masalah-masalah ilmiah yang terkandung dalam bahan ajar.

Idealnya sebuah bahan ajar yang dikembangkan dan ditulis harus tetap berpedoman pada prinsip belajar aktif, yaitu suatu proses belajar yang disertai adanya aktivitas mental dan atau aktivitas fisik yang dapat

\footnotetext{
${ }^{15}$ Seels, Instructional Technology, 15.

16 Atruf, "Pengembangan Program Pembelajaran dalam Upaya Meningkatkan Kualitas Proses Belajar Mengajar." Makalah Seminar Nasional Teknologi Pendidikan dan Kongres II Ikatan Teknologi Pendidikan Indonesia (Malang : 17-19 Nopember 1992).

17 Pannen Paulina dan Purwanto, Penulisan Bahan Ajar (Jakarta : Pau - PPAI, Universitas

Terbuka, 2001), 25.
} 
mengoptimalkan pencapaian hasil belajar.18 Karenanya bahan ajar dalam rancangannya hendaknya memuat sejumlah materi pembeajaran yang akan disampaikan oleh guru dalam kegiatan pembelajaran sesuai tingkatan atau kelas dan semesternya untuk kemudian disesuaikan dengan metode, media, dan jenis alat evaluasi dalam terapan pembelajaran.

Sudah barang tentu bahan pembelajaran atau materi pembelajaran yang akan diberikan oleh guru memiliki manfaat baik bagi guru maupun bagi siswa. Manfaat yang sangat dirasakan oleh guru maupun siswa dari penyiapan bahan pembelajaran adalah (1) jika diberikan kepada siswa sebelum kegiatan belajar dan pembelajaran berlangsung maka siswa dapat mempelajari lebih dahulu materi yang akan dibahas sehingga siswa, (2) memiliki kemampuan awal (entry behavior) yang memadai untuk mengikuti kegiatan belajar dan pembelajaran sehingga dapat men capai keberhasilan belajarnya yang maksimal, (3) dapat diharapkan partisipasi aktifnya dalam diskusi dan tanya jawab ketika kegiatan belajar dan pembelajaran berlangsung, (4) pembelajaran di kelas berjalan dengan lebih efektif dan efisien karena waktu yang tersedia dapat digunakan sebanyak-banyaknya untuk kegiatan belajar dan pembelajaran yang interaktif seperti tanya jawab, diskusi, dan kerja kelompok; dan (5) siswa dapat mengembangkan kegiatan belajar mandiri dengan kecepat annya sendiri. ${ }^{19}$

Penyusunan bahan pembelajaran yang baik atau bahan pembelajaran yang dapat mempermudah siswa memahami materi pembelajaran yang sedang dipelajari, bilama sesuai dengan kriteria yaitu (1) bahan pembelajaran hendaknya sesuai dengan topik yang dibahas, (2) memuat intisari atau informasi pendukung untuk memahami materi yang dibahas, (3) disampaikan dalam bentuk kemasan dan bahasa yang singkat, padat, sederhana sistematis, sehingga mudah dipahami, (4) jika perlu dilengkapi contoh dan ilustrasi yang relevan dan menarik untuk lebih mempermudah memahami isinya, (5) sebaiknya diberikan sebelum berlangsungnya kegiatan belajar dan pembelajaran sehingga dapat dipelajari terlebih dahulu oleh siswa, dan (6) memuat gagasan yang bersifat tantangan dan rasa ingin tahu siswa. ${ }^{20}$

18 Purwanto dan Sadjati, I. M, Editor., Pendekatan Inovatif Instructional System Design dalam Perancangan dan Pengembangan Bahan Ajar. Dalam Dwi Padmo. Teknologi Pembelajaran: Peningkatan Kualitas Belajar melalui Teknologi Pembelajaran (Jakarta : Pusat Teknologi Komunikasi dan Informasi Pendidikan, 2004), Cet. 1, 415-438.

19 Ginting, Esensi Praktis Belajar \& Pembelajaran, 153-154.

20 Ginting, Esensi Praktis Belajar \& Pembelajaran, 154. 
Selain memperhatikan kriteria di atas, maka guru sebagai perancang bahan ajar perlu juga memperhatikan kriteria pengembangan bahan ajar yaitu (1) dapat membantu kegiatan pembelajaran secara individu, (2) dapat merespon secara maksimal, (3) memuat pesan secara potensial, (4) mampu memberikan kesempatan belajar yang diminati, dan (5) memberikan saran dan petunjuk serta informasi balikan tentang tingkat kemajuan belajar yang dicapai siswa. ${ }^{21}$ Dengan demikian rancangan bahan ajar yang baik akan selalu berpijak pada tori sistem, yang mana hasil dari pendekatan teori sistem diharapkan dapat memecahkan masalah-masalah pembelajaran secara efektif dan efisien. ${ }^{22}$

Jika semua perangkat tersebut di atas dipersiapkan dan disajikan dalam bahan ajar akan dapat memberikan kemudahan baik bagi siswa dalam mempelajari dan memahami bagian-bagian yang terdapat dalam bahan ajar, sehingga dengan demikian akan terjadi perubahan pada dirinya. Demikian juga bagi guru, dengan tersajinya bahan ajar yang sesuai kriteria sebuah bahan ajar yang baik yaitu terpenuhi beberapa kriteria seperti tersebut di atas, maka akan memudahkan guru dalam memilih dan menyajikan bahan tersebut, sehingga tujuan pembelajaran yang diharapkan dalam kegiatan pembelajaran melalui penyampaian pesan dalam bahan ajar akan dapat tercapai.

Dalam merancang pengembangan bahan ajar yang dipedomani dalam kegiatan pembelajaran, sejumlah model dapat dijadikan sebagai acuannya, salah satunya adalah model Dick \& Carey yang menggunakan pendekatan sistem dengan langkah-langkah yang lengkap yaitu (1) Identify Instructional Goals, (2) Conduct Instructional Analysis, (3) Identify Entery Behaviors Characteristics, (4) Write Permormance Objectives, (5) Develop Criterion referenced Test Items, (6) Develop Instructional Strategy, (7) Develop and Select Instructional Materials, (8) Design and Conduct Formative Evaluation, (9) Revise Instruction, (10) Design and Conduct Summative Evaluation" 23. Yang diperjelas oleh Hamzah B. Uno yaitu ((1) mengidentifikasi tujuan umum pengajaran, (2) melakukan analisis pembelajaran, (3) mengidentifikasi tingkah laku masukan dan karaktristik siswa, (4) merumuskan tujuan performansi, (5) mengembangkan butirbutir tes acuan patokan, (6) mengembangkan strategi pembelajaran, (7)

${ }^{21}$ B.H. Benathy, Instructional System Design: dalam R.M. Gagne, (ed) Instructional Technology Fundation (Hallsdate: Lowrence Erlbaun Assiciations, 1987), 54.

22 A. Suparman, Desain Instruksional (Jakarta: Departemen Pendidikan dan Kebudayaan Universitas Terbuka, 1991), 68.

23 Walter Dick and Lou Carey, The Systematic Design of Instruction: Third Edition (Amerika : United States of Amerika, 1990), 2 - 3.

Jurnal Pendidikan Agama Islam (Journal of Islamic Education Studies)

Volume 5 Nomor 1 (2017)

ISSN(p) 2089-1946\& ISSN(e) 2527-4511

Hal. 52 - 67 
mengembangkan dan memilih material pembelajaran, (8) medesain dan melaksanakan evaluasi formatif, (9) merevisi bahan pembelajaran, dan (10) mendesain dan melaksanakan evaluasi sumatif. ${ }^{24}$

Ke 10 langkah dalam terapan model Dick \& Carey di atas dalam petunjuknya bahwa hasil dari langkah 1 sampai dengan langkah ke 8, jika tidak berhasil, maka akan menjadi dasar pelaksanaan langkah ke 9 memperbaiki bahan pembelajaran, yang sasaran perbaikan diarahkan mulai langkah ke 1 sampai langkah ke 8. Tetapi jika langkah ke 9 atau perbaikan dari langkah 1 sampai dengan ke 8 tidak dilakukan, maka diteruskan ke langkah ke 10 .

Langkah-langkah yang secara runtun sebagaimana yang terdapat dalam Model Dick \& Carey di atas akan ditemukan pula ketika menjadikan model lainnya dalam merancang pengembangan bahan ajar.

\section{c. Karakteristik Bahan Ajar Fiqih Madrasah Aliyah}

Madrasah Aliyah yang merupakan salah satu lembaga pendidikan pada jenjang pendidikan menengah yang dikelola Kementerian Agama, menjadikan Mata Pelajaran Fikih sebagai salah satu dari sejumlah mata pelajaran agama selain al-Qur'an-Hadits, Aqidah-Akhlak, Sejarah Kebudayaan Islam (SKI) dan Bahasa Arab yang dipelajari oleh siswa dalam upaya mencapai tujuan institusional/tujuan kelembagaan dengan menjadikan Ijazah yang diterima oleh siswa sebagai wujud keberhasilannya.

Tujuan kelembagaan tersebut dalam pencapaiannya menuntut terlebih dahulu pencapaian tujuan kurikuler yang dimplementasikan melalui terapan pelajaran guna tercapainya tujuan instruksional, yang dalam konteks ini bahan ajar yang memuat keenam komponen pebelajaran (tujuan, materi, metode, media, evaluasi dan komponen kegiatan pembelajaran), sehingga melalui terapan komponen-komponen tersebut dapat mengarahkan ketercapian tujuan pembelajaran baik terkait dengan

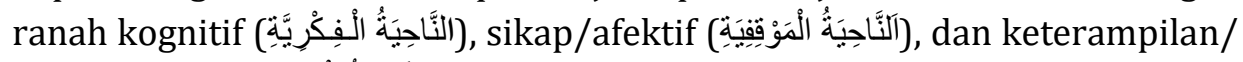

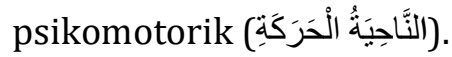

Bahan Ajar Fikih Madrasah Aliyah khususnya Kelas X memiliki karakteristik yang tentunya berbeda dengan karaktristik bahan ajar lainnya dalam lingkup pembelajaran Agama Islam (Qur'an-Hadis, AqidahAkhlak, dan SKI) baik dilihat dari standar kompetensi, kompetensi dasar, indikator kompetensi dan materi pembelajaran yang hal ini tentunya

${ }^{24}$ Hamzah B. Uno, Perencanaan Pembelajaran (Jakarta : Bumi Aksara, 2006), 24 - 33. 
berdampak pada perbedaan strategi/metode, media dan jenis alat evaluasi pembelajaran. Bahan ajar Fikih Kelas X Madrasah memuat materi 10 materi untuk pembelajaran dua semester (ibadah dalam Islam, zakat, haji, kurban dan akikah serta jenazah untuk semester pertama, dan perekonomian dalam Islam, pelepasan dan perubahan harta, kepemilikan dan akad, Wakălah, Șulḥu, Damān dan Kafālah, serta riba, bank dan asuransi untuk semester kedua).

Karena memuat 10 Standar Kompetensi,11 Kompetensi Dasar dan 106 Indikator Kompetensi dengan rincian 28 Indikator Kompetensi pada semester pertama dan 78 pada semester kedua.

\section{d. Landasan Teoritik Pemilihan Model Dick \& Carey pada Pengembangan Pembelajaran Fikih Kelas X Madrasah Aliyah.}

Pembelajaran atau proses belajar mengajar merupakan upaya untuk mempengaruhi pebelajar/siswa agar belajar. ${ }^{25}$ Atau pengaturan kemungkinan-kemungkinan, dimana pembelajaran bisa terjadi. Kemungkinan-kemungkinan itu adalah kondisi-kondisi yang membentuk tingkah laku individu di dalamnya adalah antecedents dan consequences. ${ }^{26}$ Yang di dalam kegiatannya terdiri dari memilih, menetapkan, dan mengembangkan metode untuk mencapai hasil pembelajaran yang diinginkan, dimana egiatan-kegiatan seperti ini pada dasarnya merupakan inti perancangan atau desain pembelajaran. ${ }^{27}$

Kegiatan pengembangan menuntut upaya rancangan atau desain dan begitu juga sebaliknya kegiatan rancangan atau desain dapat diarahkan dalam kegiatan pengembangan. Ini mengingat desain pembelajaran merupakan sebuah proses yang sistematik yang melibatkan penciptaan mengenai detail yang spesial untuk mengembangkan, mengimplementasikan, mengevaluasi, dan me melihara fasilitas pembelajaran (materi dan aktivitas pembelajaran). ${ }^{28}$ Atau mendesain

25 I Nyoman Sudana Degeng, Ilmu Pengajaran: Taksonomi Variabel (Jakarta: P2LPTK: Dirjen Dikti, Departemen Pendidikan dan Kebudayaan, 1989), 32.

26 Shumin Kang, "Instructional Design and Development: A Brief Hostorical Overview". Educational Technology Nomor 44 (Volume 6, 2004), 38.

27 I Nyoman Sudana Degeng dan Yusufha Dimiarso, Terapan Teori Kognitif dalam Desain Pembelajaran (Jakarta : Proyek Pengembangan Pusat Fasilitas Bersama Antara Universitas/IUC (Bank Dunia XVII), Ditjen Dikti, Depdikbud, 1993), 18.

28 Sasha A. Barab, "Using Design to Advance Learning Theory, or Using Learning Theory Advance Design" Educational Technology Nomor 44 (Volume 3, 2004), 16-20.

Jurnal Pendidikan Agama Islam (Journal of Islamic Education Studies)

Volume 5 Nomor 1 (2017)

ISSN(p) 2089-1946\& ISSN(e) 2527-4511

Hal. $54-67$ 
pengembangan produk pembelajaran dan lingkungan guna mencapai tujuan khusus pembelajaran secara efektif dan efisien. ${ }^{29}$

Untuk dapat merancang/mendesain pembelajaran dengan baik, seorang perancang pembelajaran/guru harus mampu memilih dan menguasai model-model desain pembelajaran, di samping penguasaan materi dan menguasai teori-teori atau ilmu pembelajaran. Salah satunya adalah model Dick \& Carey yang memiliki kelebihan-kelebihan yaitu menggunakan pendekatan sistem dengan langkah-langkah yang lengkap dan dapat digunakan untuk merancang pembelajaran yang lebih sistematis ${ }^{30}$, dapat digunakan untuk mengembangkan pembelajaran pada ranah informasi verbal, ketrampilan intelektual, keterampilan psikomotor, dan sikap, memungkinkan untuk mengelaborasi materi menjadi lebih rinci ${ }^{31}$, memungkinkan untuk menghasilkan paket pembelajaran yang lebih baik karena sudah melalui bermacam tahapan uji coba dan kerjasama dengan ahli rancangan pembelajaran, ahli media pembelajaran dan ahli isi, didasarkan pada teori pembelajaran preskriptif yakni berorientasi pada tujuan (goal oriented). ${ }^{32}$

Beberapa penelitian juga mengungkapkan keberhasilan pengembangan dengan model Dick \& Carey dalam meningkatkan perolehan belajar. Husein, mengungkapkan bahwa pengembangan dengan menggunakan model Dick \& Carey dapat meningkatkan perolehan belajar sebesar 3,80 dari tes awal33. Demikian juga Supriyadi, yang menyakan bahwa adanya peningkatan yang signifikan rerata skor pasca tes dengan

${ }^{29}$ David M. Merrill, "The Science of Instruction and The Technology of Instructional Design" Educational Technology Nomor 44 (Volume 3, 2004), 45-46.

30 Pernyataan ini diperkuat oleh Braden (1996) dalam Cennamo \& Kalk yang menyatakan bahwa jika mendesain pembelajaran yang efektif dan efisien maka perlu dipilih model pembelajaran yang dibuat tidak membingungkan. Juga diperkuat oleh Moisey, yang menyakan bahwa Model Dick \& Carey (1990) memberikan kerangka desain pembelajaran sistematik. Aplikasi kerangka ini memberikan efisiensi dan efektifitas dan menciptakan pembelajaran yang menjamin pebelajar memperoleh pengetahuan dan ketrampilan yang mereka butuhkan.

31 Pernyataan ini diperkuat oleh Degeng, yang mengungkapkan bahwa dengan melakukan tahapan-tahapan elaborasi akan membuat pengajaran bergerak dari umum ke khusus (urutan elaboratif). Jadi dengan mengikuti urutan elaborasi memungkinkan penyajian konstruk isi menjadi lebih rinci.

32 Pernyataan diperkuat oleh Yusuf Hadi Miarso yang menyatakan bahwa teori preskriptif bertujuan untuk memecahkan masalah Miarso, menyatakan bahwa teori preskriptif bertujuan untuk memecahkan masalah.

33 Muhammad Husein, "Pengembangan Paket Pembelajaran Dasar Listrik dan elektro Model Walter Dick and Lou Carey pada SMK Muhammadiyah 1 Malang” (Tesis, Malang, 2003), 113. 
skor pretes 34. Begitu pula dengan hasil penelitian Astina, yang mengungkapkan bahwa adanya peningkatan perolehan belajar sebesar 80 $\%$ didasarkan analisis tes perolehan belajar. ${ }^{35}$

Namun demikian model ini juga memiliki kelemahan, yakni sifatnya tidak fleksibel sehingga kurang mampu untuk mengakomodasikan aspirasi pemakainya. Sangat berbeda sekali dengan model desain nonlinier yang lebih bersifat fleksibel dan konkrit, seperti desain R2D2, Layer of Nagotiation, Chaose Theory ID dan A Maze". ${ }^{36}$ Karena itu perlu diupayakan oleh setiap perancang bahan ajar untuk selalu mencari upaya dalam mengatasi kelemahan yang terdapt dalam rancangan model Dick \& Carey ini.

\section{Media Pembelajaran}

\section{a. Manfaat Media dan Media Audio Visual dalam Pembelajaran}

Media yang dalam kegiatan pembelajaran merupakan salah satu komponen pembelajaran selain komponen tujuan pembelajaran, materi pembelajaran, kegiatan belajar mengajar, metode pembelajaran dan evaluasi pembelajaran. Penerapan media dalam kegiatan pembelajaran termasuk media audio visual (CD) dimaksudkan untuk memberikan kemudahan bagi siswa yang memerankan audio dan visual ketika menerima informasi. Hal ini mengingat siswa dalam menerima informasi pembelajaran ada menerankan audio (telinga), visual (telinga), audiovisual (telinga-mata), dan kinestetik (sentuhan perasaan).

Terkait dengan pemanfaatan media dalam kegiatan pembelajaran yang diperoleh baik guru dan atau siswa, yaitu (a) penyampaian materi pelajaran dapat diseragamkan, dimana ketika guru mempunyai penafsiran yang beraneka ragam tentang sesuatu hal, maka dengan penerapan media dalam kegiatan pembelajaran penafsiran yang beragam itu dapat direduksi dan disampaikan kepada siswa secara seragam. Setiap siswa yang melihat atau mendengar uraian tentang suatu ilmu melalui media yang sama akan menerima informasi yang persis sama seperti yang diterima temantemannya, (b) proses pembelajaran menjadi lebih menarik, dengan menerapkan media dalam kegiatan pembelajaran guru akan dapat menyampai kan informasi yang dapat didengar (audio) dan dapat dilihat

\footnotetext{
${ }^{34}$ Supriyadi, "Pengembangan Bahan Pembelajaran Mata Kuliah Perpustakaan Sekolah dengan Model Dick \& Carey" (Tesis, Malang, 1999), 150.

35 I Nyoman Gede, Astina, "Pengembangan Paket Pembelajaran Teknik Penyajian Minuman 1 dengan Menerapkan Rancangan Model Dick \& Carey" (Tesis, Malang, 1999), 135.

${ }^{36}$ J. Willis, "The Maturing of Consteruktivist Instructional Design: Some Basic Principles that can Guide Practice”, Educational Technology Vol. 40 Nomor 1 (2000), 5-16. 
(visual) oleh siswa, sehingga dapat mendeskripsikan suatu masalah, suatu konsep, suatu proses atau prosedur yang bersifat abstrak dan tidak lengkap menjadi lebih jelas dan lengkap. Dengan penerapan media dalam kegiatan pembelajaran juga akan dapat menghadirkan "masa lampau" ke masa kini, menyajikan gambar dengan warna yang menarik. Dengan menerapkan media dalam kegiatan pembelajaran akan dapat juga membangkitkan keingintahuan siswa, meransang mereka untuk beraksi terhadap penjelasan guru, membuat mereka terbawa atau ikut sedih, memungkinkan mereka menyentuh objek kajian pelajaran, membantu mereka menkonkret kan sesuatu yang abstrak. Dengan penerapan media dalam kegiatan pembelajaran akan dapat membantu guru untuk menghidupkan suasana kelas dan menghindarkan kelas dalam suasana yang menoton dan membosankan, (c) proses belajar siswa menjadi lebih interaktif, ini mengingat dengan penerapan media dalam kegiatan pembelajaran akan dapat membantu guru dan siswa melakukan komunikasi dua arah secara aktif. Dengan penerapan media guru dapat mengatur kelas sehingga kelas bukan hanya didominasi oleh guru atau guru yang aktif, tetapi juga siswa yang lebih banyak berperan, (d) jumlah waktu belajar-mengajar dapat dikurangi, dimana dengan penerapan media dalam kegiatan pembelajaran kebiasaan guru yang cukup banyak menghabiskan waktu untuk menjelaskan suatu materi, akan dapat di kurangi atau tidak akan menghabiskan waktu yang banyak, (e) kualitas belajar siswa dapat ditingkatkan, dimana penggunaan media tidak hanya membuat proses belajar-mengajar lebih efisien, tetapi juga membantu siswa menyerap materi pelajaran secara lebih mendalam dan utuh. Pemahaman siswa akan lebih baik bilamana pemahamannya itu di perkaya dengan kegiatan melihat, merasakan, menyentuh, atau mengalami melalui media, (f) proses belajar dapat terjadi di mana saja dan kapan saja, ini bilamana media pembelajaran dirancang sedemikian rupa sehingga siswa tidak lagi selalu merasa ketergantungan pada keberadaan seorang guru. Keberadaan program-program audio-visual atau program komputer yang saat ini banyak tersedia di pasaran adalah merupakan cntoh media pendidikan yang memungkinkan siswa belajar secara mandiri, (g) sikap positif siswa terhadap bahan pelajaran maupun terhadap proses belajar itu dapat ditingkatkan, yang hal ini akan berdampak pada peningkatan kecintaan dan apresiasi siswa terhadap ilmu pengetahuan dan proses pencarian ilmu itu sendiri, dan (h) peran guru dapat berubah ke arah yang lebih positif dan produktif, sebab dengan menggunakan media dalam kegiatan pembelajaran, pertama guru tidak perlu mengulang-ulang 
penjelasannya. Kedua, ketika guru mengurai uraian verbal (lisan), guru dapat memberi perhatian lebih banyak kepada aspek-aspek lain dalam pembelajar an. Ketiga, peran guru tidak lagi menjadi sekedar "pengajar", tetapi juga konsultan, penasihat, atau manajer pembelajaran. ${ }^{37}$

Juga dinyatakan oleh Yunus yaitu :

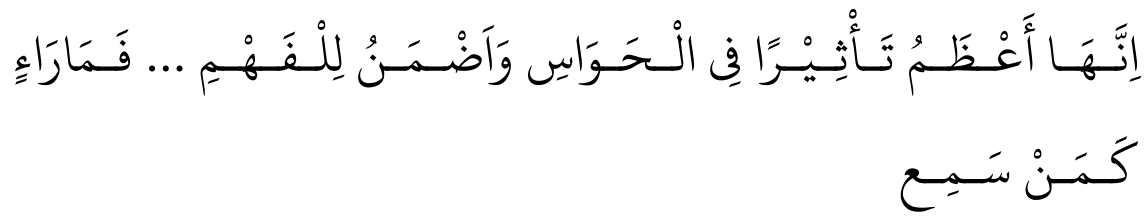

Bahwasanya media pembelajaran paling besar pengaruhnya bagi indera dan lebih dapat menjamin pemahaman ... orang yang mendengarkan saja tidaklah sama tingkat pemahamannya dan lamanya bertahan apa yang dipahaminya dibandingkan dengan mereka yang melihat, atau melihat dan mendengarnya. ${ }^{38}$

Demikian juga Ibrahim memberikan pernyataan tentang yaitu :

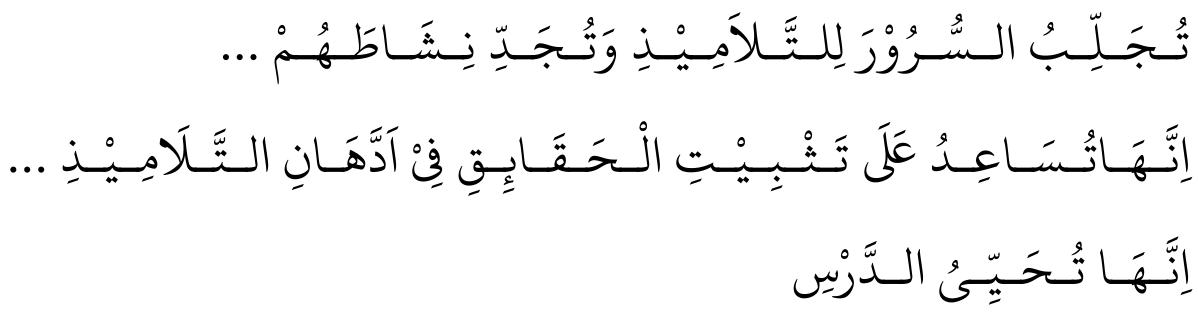

Media pembelajaran membawa dan membangkitkan rasa senang dan gembira bagi murid-murid dan memperbaharui semangat mereka ... membantu memantapkan pengetahuan pada benak para siswa serta menghidupkan pembelajaran. ${ }^{39}$

Penguatan akan manfaat media dalam kegiatan pembelajaran dinyatakan pula oleh Nana Sudjana dan Ahmad Rivai bahwa media pengajaran dapat mempertinggi proses belajar siswa yang pada gilirannya dapat mempertinggi hasil belajar yang dicapai siswa, sebab dengan penerapan media dalam proses pembelajaran, maka (a) pengajaran akan lebih menarik perhatian siswa sehingga dapat menumbuhkan motivasi belajar, (b) bahan pelajaran akan lebih jelas maknanya sehingga dapat lebih dipahami oleh para siswa, dan memungkinkan siswa menguasai tujuan pengajaran lebih baik, (c) metode mengajar akan lebih bervarisi,

\footnotetext{
37 Martinis Yamin, Desain Pembelajaran Berbasis Tingkat Satuan Pendidikan (Jakarta : Gaung Persada Press, 2009), 179-181.

38 Mahmud Yunus, التربية والتعليم (Padang Panjang : Matbaah, 1942), 78.

${ }^{39}$ Abdulhalim Ibrahim, الموجه الفني لمدرس اللغة العربية (Daarulmaarif: Cairo, 1962), 432.

Jurnal Pendidikan Agama Islam (Journal of Islamic Education Studies)

Volume 5 Nomor 1 (2017)

ISSN(p) 2089-1946\& ISSN(e) 2527-4511

Hal. 58 - 67
} 
tidak semata-mata komunikasi verbal melalui penuturan kata-kata oleh guru, sehingga siswa tidak bosan dan guru tidak kehabisan tenaga, apalagi bila guru mengajar untuk setiap jam pelajaran, dan (d) siswa lebih banyak melakukan kegiatan belajar, sebab tidak hanya mendengarkan uraian guru, tetapi juga aktivitas lain seperti mengamati, melakukan, mendemonstrasikan dan lain-lain. ${ }^{40}$

Terkait dengan media audio-visual diperoleh manfaatnya yaitu (a) rasa saling pengertian dan simpati antara guru dan siswa dan antara siswa dengan siswa di dalam kelas menjadi meningkat, (b) terjadinya perubahan tingkah laku siswa yang signifikan, (c) menunjukkan hubungan antara mata pelajaran dan kebutuh an dan minat belajar siswa meningkatnya motivasi belajar siswa, (d) membawa kesegaran dan variasi bagi pengalaman belajar siswa, (e) membuat hasil belajar bermakna bagi berbagai kemampuan siswa, (f) mendorong pemanfaatan yang bermakna dari mata pelajaran dengan jalan melibatkan imajinasi dan partisipasi aktif yang mengkibatkan meningkatnya hasil belajar, (g) memberikan umpan balik yang diperlukan siswa dalam membantu menemukan seberapa telah mereka pelajari, (h) melengkapi pengalaman siswa untuk mengembangkan konsep-konsep yang bermakna, (i) memperluas wawasan dan pengalaman siswa yang mencerminkan pembelajaran nonverbalistik dan membuat generalisasi yang tepat, dan (y) meyakinkan diri bahwa urutan dan kejelasan pikiran yang siswa butuhkan jika mereka membangun struktur konsep dan sistem gagasan yang bermakna. ${ }^{41}$

Hal ini mengingat media audio visual dalam terapan pembelajaran dimaksudkan manakala guru menghendaki penyampaian materi pembelajaran dengan memanfaatkan mesin-mesin mekanik dalam menyampaian pesan-pesan audio dan visual. Media berbasis audio visual dipahami pula media penyaluran pesan dengan memanfaat kan indera pendengaran dan penglihatan. ${ }^{42}$

Pembelajaran berbasis audio visual merupakan kegiatan menyampaikan materi pembelajaran yang menekankan pada pemanfaatan mata dan telinga, dengan bantuan perangkat lunak atau sofware yang disajikan dengan alat dukung perangkat keras atau hadware sehingga

\footnotetext{
40 Sudjana dan Rivai, Media Pengajaran, 2.

41 E. Dale, Audiovisual Methos in Teaching. Third Edition (New York: The Dryden Press, Holt, Rinehart and Winston, Inc, 1969), 180.

42 Sukiman, Pengembangan Media Pembelajaran (Yogyakarta: Pustaka Insan Madani, 2012), 184.
} 
dapat menampilkan pesan di samping gambar yang memperjelas isi pesan sehingga siswa dapat dengan mudah menangkap nya.

Media audio visual dalam perkembangan sebagai media pembelajaran diklasifikasi menjadi tiga jenis yaitu media film, video dan televisi/TV43, yang memiliki kelebihan dan kekurangan. Kelebihannya (a) dapat melengkapi pengalaman-pengalaman dasar dari peserta didik ketika mereka membaca, berdiskusi, dan ber praktik, (b) dapat menggambarkan suatu proses secara tepat yang dapat disaksikan secara berulang-ulang jika dipandang perlu. Seperti langkah yang benar dalam berwudu', praktik salat fardu dan lainnya, (c) di samping dapat mendorong dan meingkatkan motivasi juga dapat menanamkan sikap dan segi-segi afektif lainnya, seperti video religi yang memuat akibat perbuatan durhaka kepada kedua orang tua dapat membuat peserta didik sadar untuk menghindari perilaku tidak baik tersebut, (d) video yang mengandung nilai-nilai positif dapat meng undang pemikiran dan pembahasan dalam kelompok peserta didik, (e) dapat menyajikan peristiwa yang berbahaya bila dilihat secara langsung seperti lahar gunung berapi atau perilaku binatang buas, (f) dapat ditunjukkan kepada kelompok besar atau kelompok kecil, kelompok yang hetrogen maupun perorangan, dan (g) pengambilan gambar yang memakan waktu satu minggu dapat ditampilkan dalam satu atau dua menit. Seperti kejadian mekarnya kembang mulai dari lahirnya kuncup bunga hingga kuncup itu mekar. ${ }^{44}$

Sedangkan kekurangannya umumnya memerlukan biaya mahal dan waktu yang banyak, pesan yang disajikan melalui video tidak selalu sesuai dengan kebutuhan dan tujuan belajar yang diinginkan, kecuali jika video dirancang dan diproduksi khusus untuk kebutuhan sendiri. 45

Dalam terapannya pada kegiatan pembelajaran media audio visual ini memerlukan keterampilan dan kecekatan guru dalam merangkai gambar sesuai tema yang dikemas dalam sebuah Video Compact Disc (VCD) atau dalam Compact Disc (CD) dan juga dalam Digital Viedo Disc (DVD).

Sejumlah materi pembelajaran PAI termasuk materi pembelajaran Fikih di dalamnya dapat diterapkan media video atau audio visual, seperti dalam pemebelajaran materi ibadah dalam Islam, zakat, haji, kurban dan akikah, serta jenazah dan materi lainnya yang pada materi-materi tersebut memerlukan contoh-contoh gerakan yang perlu diperlihatkan oleh guru

43 Sukiman, Pengembangan Media Pembelajaran, 184.

${ }^{44}$ Azhar Arsyad, Media Pembelajaran (Jakarta : Raja Grafindo Persada, 2002), 49.

${ }^{45}$ Arsyad, Media Pembelajaran, 190.

Jurnal Pendidikan Agama Islam (Journal of Islamic Education Studies)

Volume 5 Nomor 1 (2017)

ISSN(p) 2089-1946\& ISSN(e) 2527-4511

Hal. 60 - 67 
Fikih dengan memanfaatkan media video/audio visual sebagai alat bantunya.

Sebagai salah satu contoh dalam pembelajaran tentang tatacara memandikan jenazah, maka guru dapat merancang media audio visual dengan mengacuan hadis Rasulullah saw. sebagai berikut:

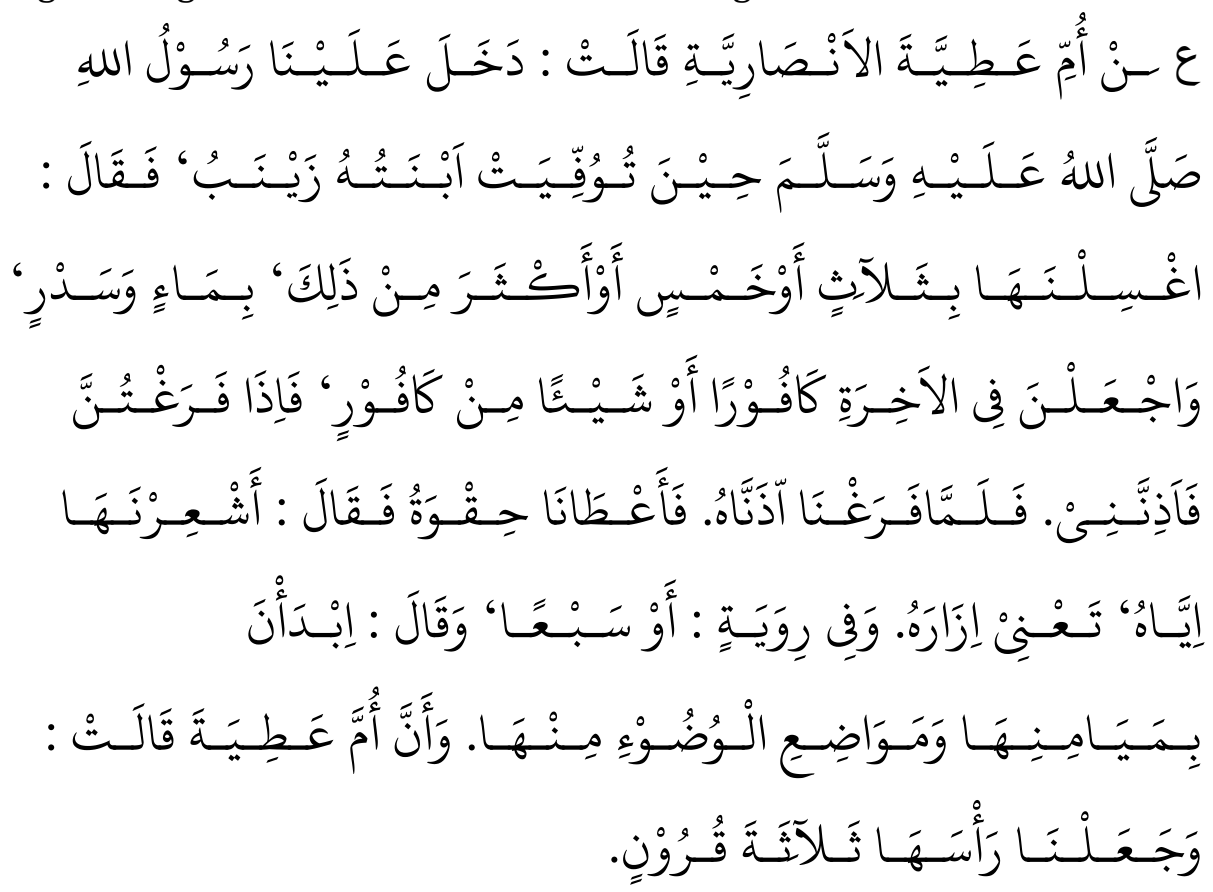

"Dari Ummu 'Athiyah al-Anshariyah radhiyallahu anha, ia berkata : Rasulullah saw. memasuki (tempat kami memnadikan), saat putrinya Zainab radhiyallahu anha meninggal dunia. Beliau bersabda : Mandikan dia dengan tiga kali atau lima kali atau lebih banyak dari itu jika kalian pandang perlu dengan air dan daun bidara, dan jadikanlah pada akhir (proses memandikan) dengan kapur (barus) atau sejenis kapur, dan jika kalian telah selesai maka beritahu aku. Ketika kami telah selesai, kami memberitahukan beliau. Tiba-tiba beliau memberikan kain sarungnya kepada kami seraya bersabda: "Bungkuslah dia dengan kain tersebut". Dan dalam satu riwayat: Atau tujuh kali. Beliau bersabda: Mulailah dari anggota tubuh bagian kanan dan anggota wudhu'nya. Dan sesunggunya Ummu 'Athiyah radhiyallahu anha berkata :"Maka kami kepang rambutnya menjadi tiga kepangan". ${ }^{46}$

Dalam penjelasan hadis ditemukan beberapa kalimat yang

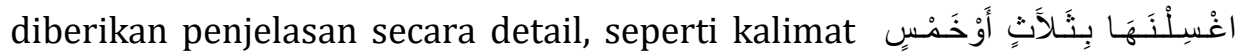

46 Syaikh Abdullah Abdurrahman Alu Bassam, تيسيـر العـلام شـرح عمدة الآحكـام Syarah Hadits Hukum Bukhari Muslim. Penterjemah: Arif Wahyudi, dkk. (Jakarta : Pustaka as-Sunnah, 2009), 420-421. 
أَوَْبْعًا memberikan kejelasan bahwa memandikan jenazah hendaknya dengan tiga kali atau lima kali atau tujuh kali dengan ketentuan tetap

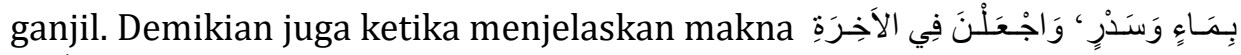
كَافُْورًا salah satu bagian air siramannya dicampur dengan daun bidara, dan pada siraman terakhir dicampur dengan kapur barus.

Hal yang sama juga ketika memberikan penjelasan dari kalimat memberikan pema haman bahwa ketika memandikan jenazah mulailah dari posisi badan si mayit/jenazah sebelah kanan, baru kemudian dilanjutkan dengan posisi sebelah kiri. Demikian juga ketika jenazah diwudu'kan juga mulai dari posisi sebelah kanan.

Memperhatikan kelebihan dan kekurangan media dalam terapannya, maka diperlukan adanya upaya maksimal guru baik dari segi kemampuan dan keteramilannya dalam merancang struktur tema atau alur sebuah perilaku yang dimuat dalam rekaman Video Compact Disc (VCD) atau Compact Disc (CD) untuk kemudian secara terampil juga memanfaatkannya sebagai media pembelajaran sehingga dapat memberikan kemudahan bagi guru dalam penerapan nya dan kemudahan bagi siswa dalam menerima pesan yang disajikan.

Sejumlah pengakuan tentang pentingnya penerapan media dalam kegiatan pembelajaran seperti tersebut di atas, bila dipilah akan terlihat jelas bahwa manfaat penerapan media baik bagi guru maupun bagi siswa. Bagi guru ketika pengajaran dilakukan (a) dapat lebih menarik perhatian siswa sehingga tumbuh motivasi belajarnya, (b) bahan ajar yang diajarkan maknanya lebih jelas, sehingga siswa lebih paham dan tujuan pengajaran lebih baik, dan (c) metode pengajaran yang diterapkan lebih bervariasi, sehingga siswa tidak menjadi bosan. Sedangkan manfaat bagi siswa dengan penerapan media dalam kegiatan pembelajaran (a) dapat menumbuhkan motivasi belajar, (b) dapat melakukan aktivitas yang beragam seperti mengamati, melakukan kegiatan, dan dapat mendemonstrasikan suatu tindakan, (c) bahan pelajaran yang diberikan guru mudah dipahami, dan menimbulkan gairah belajar.

\section{b. Media Sebagai Bahasa Guru dalam Proses Pembelajaran}

Terjalinnya komunikasi harmonis antara guru dan siswa dalam interaksi pembelajaran mutlak diperlukan, karena itu guru perlu memahami proses tahapan-tahapan komunikasi tersebut, yang menurut Onong Uchjana Effendi, membagi tahapan proses komunikasi menjadi dua, yaitu : Pertama, proses komunikasi secara primer adalah proses 
penyampaian pikiran dan atau perasaan seseorang kepada orang lain dengan menggunakan lambang atau simbul sebagai media. Lambang sebagai media primer dalam proses komunikasi adalah bahasa, kial, isyarat, gambar, warna dan lain sebagainya yang secara langsung mampu "menerjemah kan" pikiran dan atau perasaan komunikator kepada komunikan. Kedua, proses komunikasi secara sekunder adalah proses penyampaian pesan oleh seseorang kepada orang lain dengan menggunakan sarana atau alat sebagai media kedua setelah memakai lambang sebagai media pertama. surat, telepon, teleteks, surat kabar, majalah, radio, televisi, film dan banyak lagi lainnya adalah media kedua yang sering digunakan dalam komunikasi. ${ }^{47}$

Pandangan di atas sejalan dengan pikiran AECT dalam Arif S. Sadiman yang menyatakan bahwa media adalah perangkat lunak (software) sebagai media pertama atau lambang/simbol yang berisi pesan atau informasi yang biasanya disajikan dengan menggunakan peralatan sebagai media kedua yang merupakan perangkat kerasnya (hardware), yakni sebagai sarana untuk dapat menampilkan pesan yang terkandung pada media tersebut. ${ }^{48}$

Pandangan di atas memberikan kejelasan bahwa media merupakan bahasa komunikasi yang dapat digunakan oleh guru ketika mengkomunikasi isi pembelajaran kepada siswa dengan memanfaatkan simbul atau gambar yang dapat ditangkap maknya oleh siswa. Penggunaan simbul dalam komunikasi telah digunakan Allah swt. dalam memberikan gambar an terhadap umat-Nya yang tidak memanfaatkan fotensi yang diberikan Allah swt. untuk mendekatkan diri kepada-Nya, sebagaimana tertuang dalam al-Qur'an surat al-A'raf ayat 179 yang berbunyi :
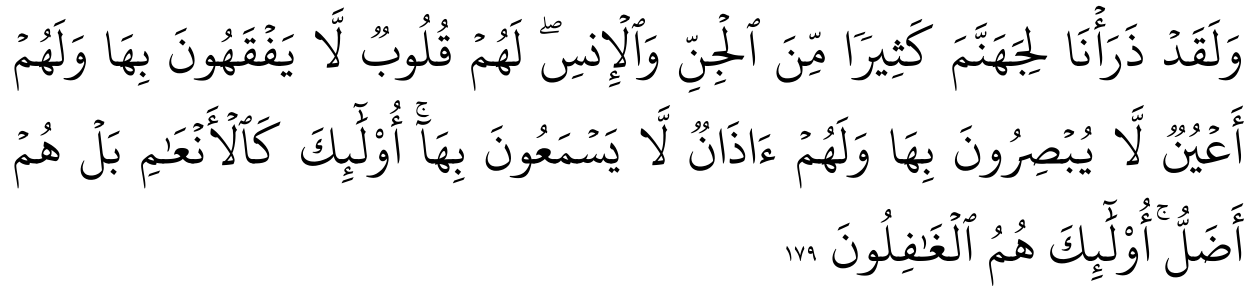

"Dan sungguh, akan Kami isi neraka Jahannam banyak dari kalangan jin dan manusia. Mereka memiliki hati, tetapi tidak dipergunakannya untuk memahami (ayat-ayat Allah) dan mereka mempunyai mata (tetapi) tidak

47 Yudhi Munadi, Media Pembelajaran Sebuah Pendekatan Baru (Jakarta: Gaung Persada Press, 2008), 8-9.

48 Arif S. Sadiman, dkk, Media Pendidikan, Pengertian, Pengembangan dan Pemanfaatan (Jakarta : Raja Grafindo Persada, 1996), 19. 
dipergunakannya untuk melihat (tanda-tanda kekuasaan Allah), dan mereka mempunyai telinga (tetapi) tidak dipergunakannya untuk mendengar (ayat-ayat Allah). Mereka seperti hewan ternak, bahkan lebih sesat lagi. Mereka itulah orang-orang yang lengah" (Q.S. al-A'raf : 179). 49

Al-Maraghi, menjelaskan ayat 179 surat al-A'raf,50 memberikan pemahaman bahwa yang bakal menjadi isi neraka ialah orang-orang bodoh dan tolol (diibaratkan binatang), yaitu orang-orang lalai yang tidak mau menggunakan akal pikiran mereka untuk memahami hakikat dari segala sesuatu, tidak mau memanfaatkan mata dan telinga mereka baik untuk menyimpulkan segala yang diketahuinya dan mengambil ilmu-ilmu maupun untuk mengetahui tanda-tanda kebesaran Allah yang ada pada alam ciptaan-Nya (ayat kauniyah) dan tanda-tanda kebesaran-Nya yang tertera dalam kitab-Nya (ayat tanziliyyah) yang kedua-duanya adalah merupakan sebab kesempurnaan iman, dan menjadi dorongan jiwa untuk menyempurnakan Islam seseorang.

Menyamakan dan bahkan menyatakan lebih rendah dengan binatang dalam ayat di atas merupakan simbul kehinaan terhadap manusi yang imannya lemah dalam pandangan Allah swt. sebab binatang yang dijadikan simbul memiliki sifat yang hanya mengikuti nafsu tanpa akal, sehingga tidak memiliki alat kontrol dalam kehidupannya.

Binatang yang dijadikan sebagai alat komunikasi oleh guru ketika menjelaskan keberadaan orang Islam yang memiliki iman yang lemah, akan dapat dengan mudah diterima oleh siswa makna yang dikehendaki dengan penjelasan guru tersebut dengan tentunya diperkuat dengan bacaan ayat yang dijadikan dasar untuk memberikan penjelasannya.

\section{Penutup}

Kajian di atas mendasari penelitian pengembangan yang menghasilkan produk pengembangan pembelajaran : bahan ajar Fikih Kelas X Madrasah Aliyah, buku panduan guru, buku panduan siswa, dan desain media pembelajaran, yang proses pengembangannya sehingga mendapatkan produk melalui uji ahli isi, uji ahli rancangan, uji ahli media, uji coba perorangan, uji coba kelompok kecil dan uji coba lapangan dengan kategori hasil akumulasi adalah bahan ajar "sangat baik" (86,43\%), buku panduan guru "baik" (85,07\%), buku panduan siswa "baik" (85,52 \%), dan desain media pembelajaran "sangat baik" ( $90 \%$ ).

Pengembangan pembelajaran (bahan ajar Fikih bermedia) pada Madrasah Aliyah di Nusa Tenggara Barat umumnya dan khususnya Lombok

\footnotetext{
${ }^{49}$ Departemen Agama RI, Al-Qur'an dan Terjemahannya, 233.

${ }^{50}$ Ahmad Musthafa Al-Maraghi, Terjemah Tafsir Al-Maraghi, Juz IX, 215.

Jurnal Pendidikan Agama Islam (Journal of Islamic Education Studies)

Volume 5 Nomor 1 (2017)

ISSN(p) 2089-1946\& ISSN(e) 2527-4511

Hal. 64 - 67
} 
Barat dan Kota Mataram masih diperlukan, mengingat keterbatasan kemampuan dan keterampilan guru Fikih dalam merancang Bahan Ajar Fikih Bermedia dan tidak tersedianya Bahan Ajar Fikih yang bermedia yang dijadikan pedoman bagi guru. Di samping itu memperthatikan manfaat bahan ajar dan media dalam pencapaian tujuan pembelajaran baik tujuan pada ranah kognitif atau

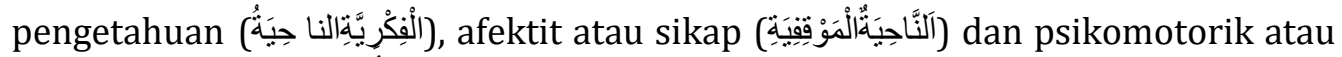

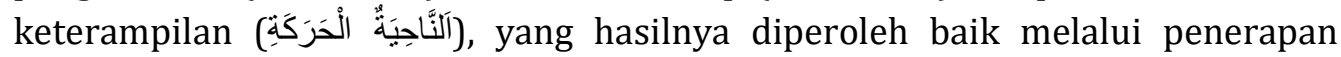

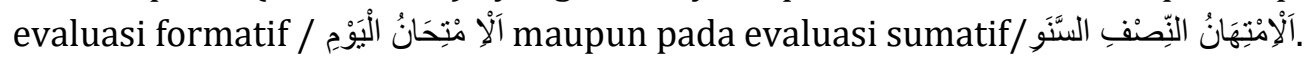

\section{Referensi}

Abdullah, Syaikh Abdurrahman Alu Bassam. تيسير العـام شرح عمدة الآحكام / Syarah Hadits Hukum Bukhari Muslim. Penterjemah : Arif Wahyudi, dkk., (Jakarta : Pustaka as-Sunnah, 2009

An-Nawawi, Imam. Riyadhus Shalihin, Syarah : Syaikh Muhammad bin Shahil AlUtsaimn, Takhrij : Syaikh Muhammad Nashiruddin Al-Albani, Tahqiq : Syaikh Musthafa Muhammad Abu Al-Ma'athi, Solo : Al-Andalus, 2015

Aqib, Zainal. Profesionalisme Guru dalam Pembelajaran. Surabaya : Insan Cendekia, 2002.

Ardhana, I Wayan. "Konsep Penelitian Pengembangan dalam Bidang Pendidikan dan Pembelajaran". Makalah disajikan dalam Lokakarya Nasional Angkatan II Metodologi Penelitian Bidang Pendidikan dan Pembelajaran, Malang, 22 - 24 Maret 2002.

Arsyad, Azhar. Media Pembelajaran. Jakarta : Raja Grafindo Persada, 2002.

Atruf. "Pengembangan Program Pembelajaran dalam Upaya Meningkatkan Kualitas Proses Belajar Mengajar" Makalah Seminar Nasional Teknologi Pendidikan dan Kongres II Ikatan Teknologi Pendidikan Indonesia, Malang: 17-19 Nopember 1992.

Barab, Sasha A. "Using Design to Advance Learning Theory, or Using Learning Theory Advance Design". Educational Technology Nomor 44 Volume 3, 2004.

Benathy, B.H. Instructional System Design: dalam R.M. Gagne, (ed.) Instructional Tecknology Fundation. Hallsdate: Lowrence Erlbaun Assiciations, 1987.

Degeng, I Nyoman Sudana, dan Yusufhadi, Miarso. Terapan Teori Kognitif dalam Desain Pembelajaran. Jakarta : Proyek Pengembangan Pusat Fasilitas Bersama Antara Universitas/IUC (Bank Dunia XVII), Ditjen Dikti, Depdikbud, 1993.

Departemen Agama RI. Al-Qur'an dan Terjamahannya Disertai Asbabun Nuzul. Jakarta: Yayasan Penyelenggara/Penafsir Al-Qur'an Revisi Terjemah oleh 
H. M. Natsir

Lajnah Pentashihan Mushaf Al-Qur'an Kementerian Agama Republik Indonesia, 2013.

Gede, I Nyoman, Astina. "Pengembangan Paket Pembelajaran Teknik Penyajian Minuman 1 dengan Menerapkan Rancangan Model Dick \& Carey". "Tesis", Program Pascasarjana Universitas Negeri Malang, Malang, 1999.

Gintings, Abdorrakhman. Esensi Praktis Belajar \& Pembelajaran : Disiapkan untuk Pendidikan Profesi dan Sertifikasi Guru-Dosen. Edisi Revisi, Bandung : Humaniora, 2008.

Gustafson, K.L. Survey of Instructional Development Models with an Annotated ERIC Bibliografy. New York: Syracuse University, 1981.

Husein, Muhammad. "Pengembangan Paket Pembelajaran Dasar Listrik dan elektro Model Walter Dick and Lou Carey pada SMK Muhammadiyah 1 Malang". "Tesis", Program Pascasarjana Universitas Negeri Malang, Malang, 2003.

Ibrahim, Abdulhalim. الموجه الفني لمدرس اللغنة العربية , Daarulmaarif : Cairo, 1962.

Kang, Shumin. "Instructinal Design and Development: A Brief Hostorical Overview". Educational Technology No. 44, Vol. 6, 2004.

Maraghi (al), Ahmad Musthafa. Terjamah Tafsir Al-Maraghi, Juz 15. Semarang: Toha Putra, 1993.

Miarso, Yusufhadi. Menyemai Benih Teknologi Pendidikan. Jakarta : Prenada Media, 2004.

Munadi, Yudhi. Media Pembelajaran : Sebuah Pendekatan Baru. Jakarta : Gaung Persada Pers, 2008.

Paulina, Pannen, dan Purwanto. Penulisan Bahan Ajar. Jakarta: Pau - PPAI, Universitas Terbuka, 2001.

Purwanto dan Sadjati, I.M., Pendekatan Inovatif Instructional System Design dalam Perancangan dan Pengembangan Bahan Ajar. Dalam Dwi Padmo (editor). Teknologi Pembelajaran : Peningkatan Kualitas Belajar melalui Teknologi Pembelajaran. Jakarta : Pusat Teknologi Komunikasi dan Informasi Pendidikan, 2004, Cet. 1.

Sadiman, Arief S., dkk. Media Pendidikan, Pengertian, Pengembangan dan Pemanfaatan. Jakarta : Raja Grafindo Persada, 1996.

Seels, B.B. \& R.C., Richey. Instructional Technology: The Definition and Domain of the Field. Washington D.C.: AECT, 1994.

Sudjana, Nana dan Rivai, Ahmad. Media Pengajaran. Bandung : Sinar Baru Algensindo, 2009. 
Sukiman, Pengembangan Media Pembelajaran. Yogyakarta: Pustaka Insan Madani, 2012.

Suparman, M. Atwi. Desain Instruksional. Jakarta: Departemen Pendidikan dan Kebudayaan Universitas Terbuka, 1991.

Supriyadi. "Pengembangan Bahan Pembelajaran Mata Kuliah Perpustakaan Sekolah dengan Model Dick \& Carey". "Tesis". Program Pascasarjana Universitas Negeri Malang, Malang, 1999.

Taufik, M. Kreativitas Jalan Baru Pendidikan Islam. Mataram : Lembaga Pengkajian-Publikasi Islam \& Masyarakat (LEPPIM) IAIN Mataram, 2012.

Undang-Undang Republik Indonesia Nomor 14 Tahun 2005, Tentang Guru dan Dosen: Dilengkapi Undang-Undang Sistem Pendidikan Nasional Peraturan Pemerintah Standar Nasional Pendidikan Peraturan Menteri Buku Teks Pelajaran, Jakarta : Karya Gemilang, 2008.

Uno, Hamzah, B., Hamzah dan Mohammad, Nurdin. Belajar dengan Pendekatan Pembelajaran Aktif, Inovatif, Lingkungan, Kreatif, Efektif dan Menarik (PAILKEM) : Strategi Pembelajaran PAILKEM Merupakan Salah Satu Strategi yang Dapat Diterapkan untuk Mengoptimalkan Kegiatan Pembelajaran di Sekolah. Jakarta : Bumi Aksara, 2011.

Walter, Dick, and Lou, Carey. The Systematic Design of Instruction. Amerika : United States of Amerika, 1990.

Willis J., "The Maturing of Consteruktivist Instructional Design: Some Basic Principles that can Guide Practice", Educational Technology. Volume 40 Nomor 1, 2000.

Yamin, Martinis. Desain Pembelajaran Berbasis Tingkat Satuan Pendidikan. Jakarta: Gaung Persada Press, 2009.

Yunus, Mahmud. التربيـة والتعليم, Padang Panjang: Matbaah, 1942. 